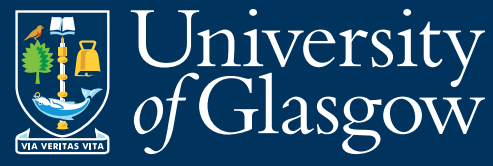

Adam Smith

Business School

WORKING

PAPER

SERIES

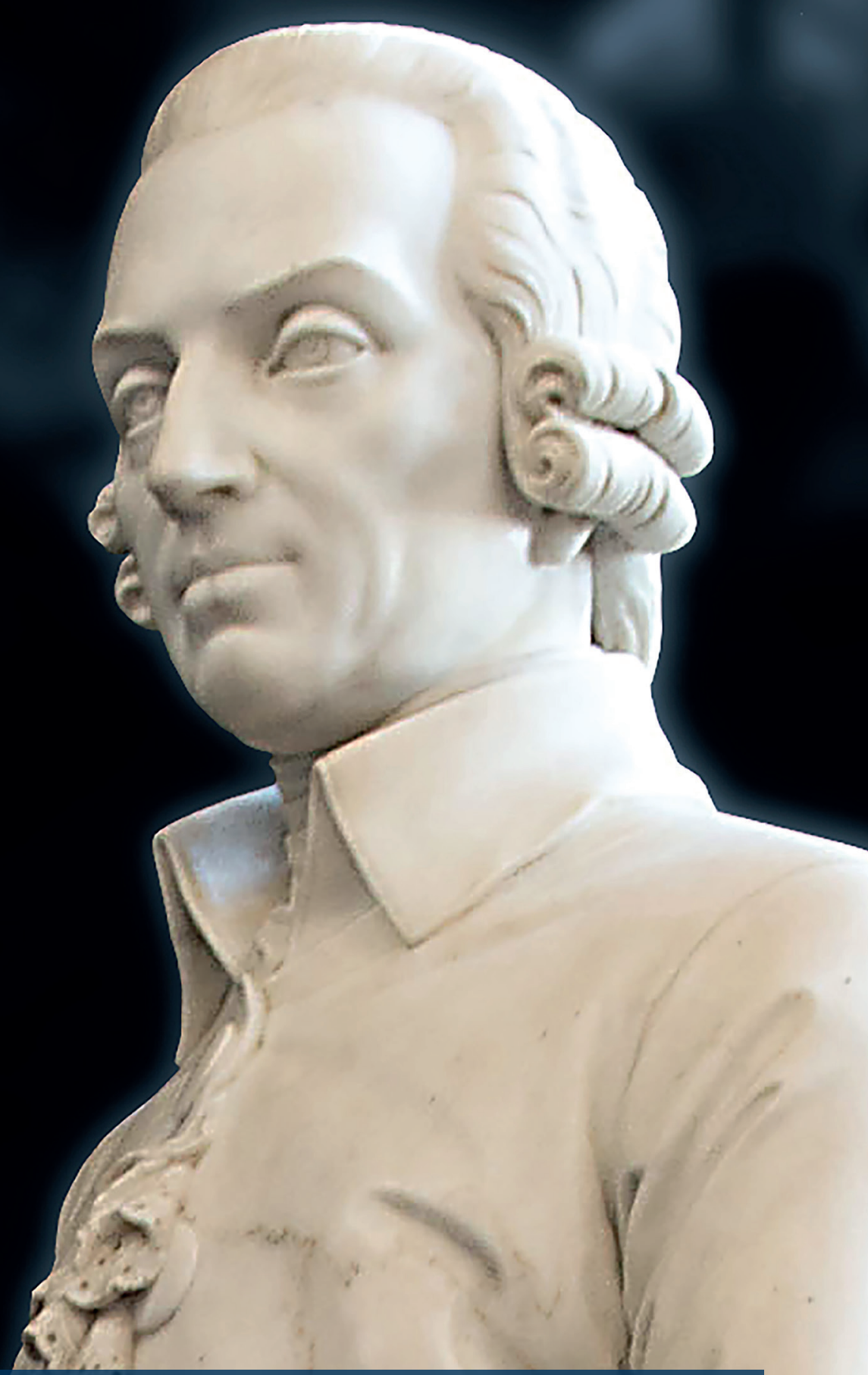

Private equity buyouts, credit constraints, and firm exports

Paul Lavery, Jose-Maria Serena, Marina-Eliza Spaliara and Serafeim Tsoukas

Paper no. 2021-06 May 2021 


\title{
Private equity buyouts, credit constraints, and firm exports*
}

\author{
Paul Lavery ${ }^{\dagger} \quad$ Jose-Maria Serena $a^{\ddagger} \quad$ Marina-Eliza Spaliara ${ }^{\S}$ \\ Serafeim Tsoukas $\mathbb{1}$
}

May 5, 2021

\begin{abstract}
We analyse the impact of private equity buyouts on firm exports, on a panel of UK non-financial firms over 2004-2017. Using difference-in-differences estimations, we show that private equity ownership increases the probability of exporting, the value of exports, and the export to sales ratio. We further show that the positive impact of private equity ownership on exports holds only after private-to-private buyouts, or acquisitions of small or young target firms. Our findings suggest that private equity investors mitigate the credit constraints faced by their portfolio companies, hence boosting their exports.
\end{abstract}

Keywords: Private equity buyouts; exporting; credit constraints; transactions.

JEL Classification: G34, G32

${ }^{*}$ We thank for their helpful comments Martin Strieborny, Nicholas Wilson, Kevin Amess and participants of the research seminars/conferences at the Bank for International Settlements, Nottingham University Business School, RES 2021 Annual Conference, Scottish Economic Society 2021 Annual Conference. The views expressed in this paper are those of their authors and not necessarily reflect the views of the Bank for International Settlements.

${ }^{\dagger}$ Adam Smith Business School, University of Glasgow, University Avenue, G12 8QQ, UK. E-mail: paul. lavery@glasgow.ac.uk

${ }_{\ddagger}^{\ddagger}$ Bank for International Settlements, Centralbahnplatz 2, 4002 Basel, Switzerland. E-mail: jose.serena@ bis.org

$\S$ Adam Smith Business School, University of Glasgow, University Avenue, G12 8QQ, UK. Email: marina. spaliara@glasgow.ac.uk

IAdam Smith Business School, University of Glasgow, University Avenue, G12 8QQ, UK. Email: serafeim.tsoukas@glasgow . ac . uk 


\section{Introduction}

Private equity (PE) buyouts have a significant impact on their targets' activities. The literature shows, for example, that PE firms help targets enhance their operating performance, both in the U.S. (Kaplan, 1989; Guo et al., 2011; Acharya et al., 2012; Fracassi et al., 2018; Cohn et al., 2020) and in Europe (Boucly et al., 2011; Chung, 2011; Biesinger et al., 2020). PE firms also help targets increase their productivity (Harris et al., 2005), investment in innovation (Lerner et al., 2011), and employment (Davis et al., 2014; Lerner et al., 2019). Nevertheless, PE investments also pose certain risks to operating performance, as they engage in financial engineering and typically increase the leverage of their targets with negative implications for performance, wages, and employment (Batt and Appelbaum, 2014, 2020). ${ }^{1}$

As far as we are aware, the literature is silent regarding how important changes of firms' organizational structure affect their international expansion and exporting activities. Accordingly, we examine whether PE investment encourages companies to expand into international markets, and we study their ensuing behaviour in export markets. Firms' exporting merits special attention, as it provides varied and diverse benefits relative to non exporting firms. Specifically, it improves firms' financial health (Greenaway et al., 2007) and their probability of survival (Bernard and Jensen, 1999a). Exporting is also associated with more efficient resource reallocation, which can increase industry productivity (Bernard and Jensen, 1999b). Moreover, evidence around employee-level benefits are that exporting firms pay higher wages than non-exporting firms do (Bernard et al., 1995; Schank et al., 2007). Finally, exporting can help to stimulate aggregate employment. Within the UK, a very recent report from the UK government estimates that UK export production supports around 6.5 million jobs, or $23 \%$ of total UK full-time equivalent jobs (Black et al., 2021). The report

\footnotetext{
${ }^{1}$ There is an ongoing debate in the U.S. related to the "Stop Wall Street Looting" act, which was unveiled by Elizabeth Warren, a U.S. senator, in response to a number of high-profile buyouts that ended in failure and left employees and pensioners in a perilous state. https://www.congress.gov/116/bills/s2155/ BILLS-116s2155is.pdf. The reform aims to hold private equity investors accountable for the debt burdens of their portfolio companies and would ultimately force investors to reconsider how they structure buyout transactions.
} 
likewise shows that the number of jobs supported by exports has increased considerably over time.

With respect to exporting, PE targets receive strategic advice, financial support, and industry specialisation. PE investors with international presence and operational knowledge of the overseas markets may offer a comparative advantage to their portfolio firms relative to non-PE-backed firms. Therefore, portfolio firms are more likely to expand their operations abroad, improve their exporting status and overcome the sunk cost of entering a foreign market. Our study provides novel evidence of how PE buyouts affect exporting among portfolio companies at the intensive and extensive margin. Specifically, we document the channel through which PE investors unlock firms' exporting potential, paying attention to relaxing financing constraints.

Our empirical work is based on a difference-in-differences analysis to estimate how PE investment affects firms' exporting status. On this basis, we define two groups of firms: treated firms with PE-backed investment, and a matched sample of non-PE-backed control firms. We match the latter group to our sample of buyout targets across four key areas: two-digit SIC industry, size, profitability, and leverage in the pre buyout year. In doing so, we construct a comprehensive panel data set of sponsored and non sponsored firms that are similar in nature prior to the acquisition of our treated sample of PE-backed firms. In the empirical analysis that follows, a probit model examines the probability of exporting among firms with and without private equity backing. We then use a difference-in-differences model to investigate how PE buyouts affect the value and intensity of firms' exports. In extensions of this, we exploit firm-level and deal-level heterogeneity to investigate whether particular segments of firms and deals perform better following PE investment. In doing so, we identify a novel channel of financing constraints: relative to the control group, treated firms display better export performance after the buyout when they are less likely to be financially constrained.

To conduct the analysis, we merge data from Standard and Poor's (S\&P) Capital IQ 
and Bureau van Dijk's FAME database. This way we link PE transaction data with firmlevel accounting data for over 1,400 buyout targets in the UK from 2004 to 2017. The UK is an ideal setting for the empirical analysis for three main reasons. First, it is the largest and most active private equity market in Europe; in recent years it had the highest average annual deal value, and aggregate annual deal value relative to GDP (Bernstein et al., 2019). ${ }^{2}$ Consistent with this, commercial data provider Pitchbook reports in its 2019 Annual European Private Equity Breakdown that the UK and Ireland account for $29 \%$ of European private equity deal value over the last 10 years, which is more than any other region in Europe. Similarly, it accounts for over 50\% of funds raised in Europe over the same period. Second, the law requires all limited companies in the UK to provide certain accounting information to the public UK register. The depth and detail of this information varies according to firm size; however, as most firms in our sample are mid-market companies, there is excellent coverage of balance sheet and income statement information in our sample. Accordingly, we have access to accounting statements for a rich dataset of firms, over $98 \%$ of which are private. Private companies in our sample are generally the smallest, youngest, and most bank-dependent firms. This is vitally important because these firms are more likely to suffer from information asymmetry problems, and hence their exporting is likely to respond more strongly to private equity investment. Finally, the UK is the sixth-largest trader in the world and the third-largest exporter of services. The British government's Department for International Trade has a strong focus on export-promotion strategies to increase the number of firms exporting in international markets. From an economic policy point of view, understanding firms' exporting is important, as export intensity, survival, and firm growth are important aspects of industry dynamics, forming the competitive landscape in an economy.

We document three main results. First, we find that PE-backed firms have a higher probability of exporting, relative to control firms. That is, PE ownership appears to improve

\footnotetext{
${ }^{2}$ Bernstein et al. (2019) also note that international comparisons of country-level private equity activity are difficult due to lack of harmonized data and definitions.
} 
firms' exporting at the extensive margin. Second, PE-backed firms have a higher exporting intensity as measured by share of export sales to total sales. Both findings are robust to controlling for various firm-level attributes and a range of fixed effects, implying that differences in exporting behavior are due to changes in organizational structure as opposed to other firm-level or macroeconomic factors. In addition, the results are economically significant. In particular, we find that the probability of exporting after a PE buyout increases by $4-5 \%$; the value of exports among PE-backed companies rises by around 30\% post-buyout relative to non sponsored firms; and the share of export sales to total sales increases by between 2\%-3\%. Finally, we present evidence that the positive effect on the probability of export, exporting value, and intensity is considerably stronger in companies more likely to be financially constrained in the pre buyout period; that is, companies that are smaller and younger in the pre buyout year experience significantly greater growth in exporting and are more likely to start exporting. At the deal level, private-to-private buyouts drive our results, as opposed to public-to-private transactions or divisional buyouts. We interpret this as evidence of private equity investors mitigating constraints facing their portfolio companies.

This paper brings together two strands of the literature on firm performance. First, we add to the literature investigating the firm-level effects of PE ownership. Previous research shows that PE firms have a positive impact on the performance of the acquired companies. This impact occurs through the easing of credit constraints of portfolio companies (Boucly et al., 2011; Davis et al., 2014; Amess et al., 2016; Bernstein and Sheen, 2016; Bernstein et al., 2019). Second, our study broadens the literature on firm-level engagement in international export markets. Existing work supports that access to financing is critical in export activities (Greenaway and Kneller, 2004; Minetti and Zhu, 2011; Manova, 2013; Muûls, 2015; Chaney, 2016). Our evidence provides a key contribution to both strands of literature by documenting the beneficial role of PE investment on firms' exporting, both at the extensive and the intensive margin.

The rest of the paper is set out as follows. In section 2, we provide a short discussion 
of the related literature and derive our testable hypotheses. Section 3 describes our data and presents some summary statistics. In section 4 we lay out our econometric modelling strategy. Sections 5 and 6 illustrate our main empirical results and robustness tests. Section 7 concludes.

\section{Hypotheses development}

\subsection{Private equity and exporting}

A large literature shows that $\mathrm{PE}$ investors can add value to their portfolio companies in a range of different ways, including through improved governance and advising on recruitment, through various forms of operational engineering, by leveraging their network of potential customers, suppliers and industry advisors, and in some cases, by advising on and facilitating bolt-on acquisitions to their target companies (for surveys on how PE investors add value to their portfolio companies see Gompers et al., 2016; Bernstein et al., 2019). In addition, PE investors often have strong relationships with the banking industry (Ivashina and Kovner, 2011) and may help target firms better weather periods of crisis (Bernstein et al., 2019). As a result, there is ample evidence that private equity targets become more productive after being acquired, in both the UK (Harris et al., 2005; Amess, 2003) and in the US (Davis et al., 2014; Lerner et al., 2019).

In the context of exporting, the implication is that PE-backed companies receive strategic advice and financial support, both of which can enable them to overcome the associated costs of exporting, allowing them to gain a foothold in foreign markets and expand their geographic reach, thus improving their exporting status. Accordingly, we anticipate a link between PE ownership and firms' ability to grow successfully in international markets. Based on this discussion, we stipulate testable hypotheses as follows:

Hypothesis 1a: Private equity investments help targets to become exporters (extensive margin). 
Hypothesis 1b: Private equity investments help targets to increase their export intensity (intensive margin).

\subsection{Inspecting the mechanism: credit constraints}

Prior research attributes value creation among private equity investors to their ability to ease financial constraints for the companies in which they invest. This effect depends on different types of buyout transactions. Specifically, heterogeneity at the deal or firm level seems to influence the degree to which PE investment affects firm performance. One strategy to identify heterogeneity is to separate public and private firms, which differ in many ways. The former are more likely to be larger, more mature, and suffer from potential agency problems (Jensen, 1986), while the latter are more likely to be smaller and financially constrained (Gao et al., 2013). Boucly et al. (2011) suggest that target firms involved in take-private transactions involving listed firms and divisional buyouts of subsidiaries of larger groups are less likely to be constrained pre-buyout, as they are more likely to have better access to capital markets. Moreover, they find that private-to-private target firms experience spectacular post-deal growth, while firms in other types of transactions do not.

Chung (2011) finds supporting evidence that investors alleviate constraints facing privateto-private firms, thereby facilitating their growth, while public-to-private target firms downsize. Similarly, Fracassi et al. (2018) shows that the sales growth in targets is predominantly in private rather than public targets. Lerner et al. (2019) observe that gains in productivity and employment occur in private target firms, as opposed to public-to-private and divisional buyouts. Likewise, Amess et al. (2016) find the positive impact of private equity ownership on firms' patenting is concentrated in private-to-private deals, and Cumming et al. (2020) show that a reduction in patents and patent citations follow public-to-private buyouts.

As well as considering different deal types, financial constraints can be identified at the firm level. Empirical evidence of firm-level international trade show that exporters significantly display better financial health than their counterparts (Greenaway et al., 2007). 
In a similar vein, Muûls (2015) analyse the interaction between credit constraints and export behaviour at the firm level. Her results show that the chances of firms being exporters are higher if they enjoy lower credit constraints and higher productivity levels. Finally, Bernstein et al. (2019) note that smaller firms, more leveraged firms, or target firms operating in more financially dependent industries outperform buyout target firms less likely to be ex-ante constrained during the global financial crisis. ${ }^{3}$

To sum up, the literature suggests that private equity investors can play an important role in relaxing financial constraints in their portfolio firms. In terms of exporting, when financially constrained firms gain access to PE funding, they are able to cover the variable trade costs and expand their sales to foreign markets. This could be explained by virtue of the fact that PE-backed firms are able to diversify their sources of financing and the associated risks. To define testable hypotheses, we assess targets' credit constraints using various attributes at the onset of the transaction. We focus on three well-established dimensions: listing status, size, and age. As private firms have limited access to external funding compared to public firms, we should expect that private-to-private buyouts might experience a more potent post-deal increase in exporting activity. Similarly, we should expect that the beneficial impact of PE on firms' exporting might be more significant for firms that are more likely to be financially constrained. Motivated by these considerations, we examine the role of deal- and firm-level heterogeneity in exporting following buyouts. Based on these arguments, our testable hypotheses are as follows.

Hypothesis 2a: Targets are more likely to experience an increase in exports in privateto-private transactions.

Hypothesis 2b: Small and young targets are likely to experience an increase in export activity.

\footnotetext{
${ }^{3}$ Boucly et al. (2011) also observe stronger growth in companies that are ex-ante more likely to be constrained pre-buyout.
} 


\section{$3 \quad$ Data and descriptive statistics}

\subsection{Sample characterization}

We construct our dataset using different data sources. First, to build our sample of private equity-backed companies, we use Standard and Poor's (S\&P) Capital IQ to identify all private equity transactions with targets in the UK. ${ }^{4}$ Capital IQ is the primary source of private equity transactions in recent academic studies. ${ }^{5}$ We consider deals shown as "completed" between 2004 and 2017. ${ }^{6}$ We omit deals which are announced but not yet completed. Following prior work, we identify private equity transactions by searching for "leveraged buyout," "going private," "management buyout," and "platform" transactions in Capital IQ. This yields an initial 7,505 private equity transactions. We then drop all deals for which there is no defined buyer/private equity investor, leaving us with 3,310 transactions.

We take all relevant information, such as transaction date, name(s) and location(s) of buyer/investor(s), transaction value, and type of transaction. Using Capital IQ, we also check the name, vintage year, and size of the PE fund through which the transaction is made. When the target company is not explicitly linked to a PE fund in Capital IQ, we take the size of the most recent fund that is in its investment period prior to the transaction (Arcot et al., 2015). In order to identify how and when the private equity investor exits a deal in each case, we use a variety of resources. We use Capital IQ's merger \& acquisition database to search for sales to trade buyers and sales to other private equity investors (secondary buyouts). We also use Factiva and manual searches of financial news for acquisitions, initial public offerings, and bankruptcies/liquidations involving the target firms. In some cases, we conduct extensive web searches on a deal-by-deal basis to deduce the ultimate outcome of

\footnotetext{
${ }^{4}$ We also rely on Thomson Reuters Eikon to supplement our deal search.

${ }^{5}$ Other authors use this database as a source of private equity buyouts (eg Strömberg, 2008; Fang et al., 2013; Jenkinson and Sousa, 2015; Bernstein and Sheen, 2016; Faccio and Hsu, 2017; Fracassi et al., 2018; Bernstein et al., 2019).

${ }^{6}$ The choice of sample years is driven by the desire to have relatively sufficient pre- and post-deal accounting information for target companies, and, as we explain later, we have data from 2000 through to 2019 .
} 
the transaction.

To source companies' financial accounts, we use the FAME database, published by Bureau Van Dijk Electronic Publishing (BvDEP). This database sources historical accounts of companies in the UK from Companies House, the national UK register. We first download company accounts (balance sheets and income statements) and static firm information (such as industry codes, location, date of incorporation) for all companies in the FAME database for 2000 through 2019. The next step is to match target firms from our list of transactions from Capital IQ to the FAME database. In order to maximize our matches, we do so manually. An advantage of FAME in this case is that it tracks firms' prior names. If company names differ between our list of transactions from Capital IQ and FAME, we verify that we are tracking the correct company by cross-checking information such as reported sales, total assets, and company address or website are consistent between the two sources. We also use Companies House in this respect. In total, we match 1,434 private equity-backed companies from Capital IQ to FAME over a 14-year period. This equates to $44 \%$ of the deals initially identified in Capital IQ with a defined private equity investor. Using similar data sources, Jenkinson and Sousa (2015) report a 40\% match from an initial sample of 2,567 exited deals involving European targets. ${ }^{7}$

\subsection{Creating a matched control sample}

To estimate the difference-in-differences models, we define a matched control group of nonPE-backed firms, which should be similar to sponsored firms in the pre buyout period. To construct a control group, we use a matching procedure inspired by Boucly et al. (2011) and Bernstein et al. (2019). Each matched control company meets the following four criteria: 1) it has the same two-digit SIC code as the target firm; 2) it has total assets in the pre deal year within a $50 \%$ bracket of the target; 3) it has a ROA in the pre deal year within a $50 \%$

\footnotetext{
${ }^{7}$ The only difference is that Jenkinson and Sousa (2015) match from Capital IQ to all of FAME, Amadeus, and Orbis, all of which are managed by Bureau van Dijk. Amadeus and Orbis provide coverage of European firms, whereas FAME only follows UK and Irish firms.
} 
bracket of the target firm, and 4) it has leverage, defined as the ratio of total debt to assets in the pre deal year within a $50 \%$ bracket of the target firm.

Using this procedure, we match up to five control firms for as many target firms as possible. Where a target generates more than five matches, we retain the five closest matches as measured by the sum of the squares of the difference between the target and the control firm's total assets, ROA, and leverage. Naturally, the choice of percentage bracket involves a trade-off between matching accuracy and finding control firms for as many targets as possible. Using a $50 \%$ bracket, we find control firms for 733 of our 1,434 private equity-backed firms, equating to $51 \%$ success in matching. ${ }^{8}$ We finish with a sample of 733 private equity-backed firms and 3,104 control firms.

\subsection{Descriptive analysis}

Table 1 provides preliminary analysis of our sample of transactions. Panel A shows the industry distribution of the target firms, which tend to be concentrated in the services and manufacturing sectors, similar to other recent work in deal-level private equity research (Chung, 2011; Jenkinson and Sousa, 2015; Bernstein et al., 2019). Other important sectors include retail trade and transportation \& communication. Panel $\mathrm{B}$ of table 1 gives a breakdown of the types of deals in our sample. Similar to studies such as Strömberg (2008), Kaplan and Stromberg (2009), Boucly et al. (2011), and Bernstein et al. (2019), the majority of the deals in our sample are private-to-private buyouts. Around 5\% are public-to-private transactions, a figure very similar to the samples in the above papers. Likewise, our proportion of secondary buyouts is also representative of the literature, which largely reports similar deal type distributions. Our sample contains a slightly lower proportion of divisional sales $(17.1 \%)$ compared to these studies. This is likely because accounting information is harder to find when divisions are carved out of companies. Finally, in panel C, we can see how the transactions are exited. Consistent with other deal samples, selling to a strategic

\footnotetext{
${ }^{8}$ This is not too dissimilar to the matching success in Bernstein et al. (2019) who report a $60 \%$ match using a similar matching technique.
} 
buyer (trade sale) or to another private equity investor (secondary buyout) are the primary forms of exit, whereas going public via an an IPO is less common (Strömberg, 2008; Kaplan and Stromberg, 2009; Jenkinson and Sousa, 2015). ${ }^{9}$ Around $65 \%$ of the transactions have experienced some form of exit.

Table 2 presents pre-buyout descriptive statistics and provides initial evidence that, by construction, our two groups of firms are fairly similar in the pre buyout period. They share similar characteristics, with the only significant exception being that private equity-backed firms have slightly higher pre buyout sales; a difference which is statistically significant only at the 10\% level. Studies such as Boucly et al. (2011) and Bernstein et al. (2019) likewise find private equity-backed firms are slightly larger relative to control firms, in terms of turnover, prior to being acquired. In any case, in all empirical specifications we augment our model with a vector of control variables (which includes firm sales) taken in the pre-buyout year. By construction, the distribution of pre-transaction profitability (ROA) and leverage is very similar across both groups, as is the size (as measured by total assets) and the industry in which they operate. Other variables such as cash flow, earnings, and firm productivity are very similar across both sets of firms. Finally, the export sales of the two groups is similar, with very little difference between the pre buyout dollar value of their export sales. However, the non-PE-backed firms tend to have a higher pre transaction exporting intensity, as measured by the ratio of export sales to total sales.

Moving a step further, table 3 explores the parallel trends assumption behind the differencein-differences model where we consider the pre-buyout three-year growth rates of various firm-level variables. ${ }^{10}$ Again, the target firms and controls exhibit similar trends across most variables. The only difference of note in the growth trends is that target firms have a slightly

\footnotetext{
${ }^{9}$ Similarly, figures from the BVCA, the leading UK industry body for private equity investors, report that of 5,533 deal divestments from 2007 to 2019, selling to trade acquirers was by far the most common exit route, with almost $25 \%$ of target companies being sold to trade.

${ }^{10}$ In the online appendix, we also provide pre-buyout one- and two-year growth rates for all variables. The results are similar, with the only key difference being that treated firms have higher one- and two-year pre-deal growth in sales.
} 
higher pre buyout growth rate in sales. ${ }^{11}$ We later show that our results hold when controlling for the pre transaction growth in sales, as well as other variables measured in the pre buyout year. Taking the static pre buyout period figures and the pre-buyout growth rates together, we can appreciate that both groups of firms are generally similar in nature in the pre transaction period.

To provide a simple visual account of the evolution of firms' exports around the transaction, we present figure 1. Specifically, the graph shows the $\alpha_{t}$ of the following equation:

$$
y_{i_{t}}=\alpha_{t}+\alpha_{i}+\varepsilon_{i t}
$$

where $\alpha_{t}$ captures year fixed effects and $\alpha_{i}$ stands for company fixed effects. The $x$ axis spans four years prior to and four years after the buyout transaction occurs. We examine a four-year window around the buyout since the average holding period of the target company is 4 years. In addition, setting up foreign supply chains and reorganising a firm to engage in exporting activities can be a lengthy process ${ }^{12}$. We use the year before the buyout as the base period and we normalize its corresponding coefficient to zero. We estimate equation 3.1 separately for both the private equity-backed and control samples, with standard errors clustered at the firm level. We observe that both our treated and control samples follow similar paths in the run-up to the transaction, after which there is a divergence in exporting behavior. This gives us an initial insight into how private equity ownership may affect the exporting behavior of target firms. Taken together, we can plausibly assume that the parallel trends assumption is satisfied.

\footnotetext{
${ }^{11}$ Boucly et al. (2011) likewise find that private equity-backed targets exhibit greater growth in sales in the pre-transaction period relative to a sample of matched control firms.

${ }^{12}$ We shorten the window where the investor exits in less than four years.
} 


\section{Empirical model}

\subsection{Extensive margin of export}

We begin our empirical investigation by testing whether PE buyout targets are more likely to become exporters, relative to the control group by estimating:

$$
\operatorname{Prob}\left(E X P_{i c t}>0\right)=\alpha_{t}+\alpha_{i}+\alpha_{c}+\beta_{1}\left(P E_{i} * \text { Post }_{i t}\right)+\beta_{2} \text { Post }_{i t}+\theta X_{i} * \text { Post }_{i t}+\varepsilon_{i c t}
$$

where $i$ is a firm index, $c$ is the firm industry, and $t$ is a year index constructed around the buyout. The dependent variable $E X P_{i c t}$ is a dummy variable that equals one if firm $i$ in industry $c$ has a positive amount of exports in year $t$, and zero otherwise. $P E_{i}$ is a dummy variable that equals one for PE-backed companies, and zero for the control group. Post ${ }_{i t}$ is a dummy variable that equals one after the buyout, and zero before. For control firms, Post ${ }_{i t}$ equals one when the matched target firm corresponding to the control has been acquired, and zero before. In line with the literature, we estimate both linear probability and probit models based on the above specifications (see Greenaway et al., 2007; Minetti and Zhu, 2011; Minetti et al., 2015; Muûls, 2015). The model also includes year fixed effects, $\alpha_{t}$; firm fixed effects, $\alpha_{i}$, which absorb the $P E_{i}$ dummy; and industry fixed effects, $\alpha_{c}$ (at the two-digit SIC code). To deal with serial correlation, we cluster standard errors at the firm level.

We also construct several firm-level control variables to control for pre-buyout heterogeneity in firm-level characteristics (captured by vector $X_{i}$ in equation 4.1). In particular, following Bernstein et al. (2019), we control for firm size (the log of sales), cash flow scaled by total assets, leverage, profitability (ROA), and earnings (EBITDA) normalized by assets. Including such controls helps to alleviate any concerns regarding any differences between the treated and control samples in the pre-buyout period. We take these control variables in the pre transaction year and interact them with the Post ${ }_{i t}$ variable in order to avoid any 
endogeneity concerns.

A positive coefficient for $\beta_{1}$ would signal that after a buyout, target firms are more likely to export than control firms. Since the matching ensures that treated and control firms are alike before the buyout, we attribute any post-buyout differences to the effect that PE firms exert on their portfolio companies. Such a result would therefore provide evidence in favour of H1a, indicating that PE firms help their portfolio companies to become exporters.

\subsection{Intensive margin of export}

In this sub-section we explore whether the value of firms' exports and their exporting intensity are affected by being backed by a private equity sponsor. To do so, we use a standard difference-in-differences (DiD) approach to estimate the changes in firm-level exporting after buyout transactions, relative to changes at control firms. ${ }^{13}$ Our baseline specification is:

$$
y_{i c t}=\alpha_{t}+\alpha_{i}+\alpha_{c}+\beta_{1}\left(P E_{i} * \text { Post }_{i t}\right)+\beta_{2} \text { Post }_{i t}+\theta X_{i} * \text { Post }_{i t}+\varepsilon_{i c t}
$$

where the dependent variable is the log of export value or export sales as a percentage of total sales. The rest of the control variables are equivalent to those in equation 4.1. The main coefficient of interest is again $\beta_{1}$, which captures the estimated change in private equity targets' exporting from before to after a buyout for target firms relative to control firms. A positive sign would reveal that PE buyouts boost target's exporting at the intensive margin, relative to the control group. This rests on the identification assumption that treated and control firms experience a similar pre-buyout growth trend in exporting. This assumption is validated by the summary statistics on pre-buyout growth rates shown in table 3 , discussed in detail in section 3. We can therefore interpret that any differences after the buyout relate to the changes brought about as a result of the buyout. Support for H1b is reflected in a positive coefficient for the $P E_{i}^{*}$ Post $t_{i t}$ interaction.

\footnotetext{
${ }^{13}$ Boucly et al. (2011), Bernstein et al. (2019), or Cohn et al. (2021) use similar models to estimate the impact of private equity on firm dynamics.
} 


\subsection{Credit constraints}

We conduct a third exercise to test whether PE firms boost the exports of the target firms through easing the credit constraints, as hypothesized in subsection 2.2. Specifically, our main interest lies in examining whether PE-backed firms facing financial constraints exhibit different sensitivities to their exporting after a buyout compared to firms in the control group. To this end, we split the sample of treated firms into two sub-samples, namely credit constrained and unconstrained targets. In order to ensure robustness, we focus on three dimensions of financial constraints: type of transaction, firm size, and firm age. Private target firms are more likely to face constraints than are publicly-listed targets or divisions of larger firms, which ought to have better access to capital markets (Boucly et al., 2011). As for firm-level heterogeneity, large firms cope well with financial constraints and have greater access to external financing, which is necessary to cover the sunk and fixed costs of exports (Greenaway et al., 2007). In addition, younger firms are more likely to face problems of asymmetric information, given that their short track record makes it more difficult to judge their quality (Guariglia, 2008). Finally, Hadlock and Pierce (2010) provide evidence that both firm size and age are particularly useful predictors of financial constraints.

To implement the test for H2a and H2b, we estimate equations 4.1 and 4.2 for two subsamples (constrained and unconstrained firms). These specifications capture how firm-level heterogeneity, measured by deal type, firm size, and firm age, affects the way exporting responds to private equity investment in firms that are more and less likely to suffer from financial constraints at acquisition. Large is a dummy variable that takes the value one if the firm's total assets are above the upper 25th percentile of the distribution of the total assets of all the firms, and zero otherwise. Old is a dummy variable that takes the value one if the firm's age is above the upper 25th percentile of the distribution of age of all the firms, and zero otherwise. We opt for the top quartile as a cut-off point due to the skewed distribution of

firm size and age, which is also consistent with previous research using UK firms (Bernstein et al., 2019). This acknowledges that a significant fraction of the firms in our sample are 
bunched at low levels of size and age; while only a small fraction of firms standing out as significantly large, or mature. To support H2a,b we expect the impact of private equity investment to be stronger for firms classified as financially constrained compared to their unconstrained counterparts.

\section{$5 \quad$ Results}

\subsection{Extensive margin of export}

We start by examining whether private equity-backed firms are more likely to be exporters, relative to comparable unsponsored firms. Specifically, we test whether the difference in the probability of exporting from the pre-deal period to the post-deal period is greater for private equity-backed firms relative to control firms. In each specification we include firm, industry, and year fixed effects. Table 4 shows the results. We report coefficient estimates and standard errors clustered at the firm-level.

In column 1 we show results of a linear probability model, which support that private equity ownership positively and significantly affect firms' probability of exporting after the $\mathrm{PE}$ transaction. This is reflected in the positive sign of the key variable of interest, namely the interaction between the firm-level dummy $P E_{i}$ and the time period dummy $P_{o s t}\left(P E_{i} *\right.$ Post $\left._{i t}\right)$. The effect is economically significant. The probability of entering the export market increases by 4.6 percentage points, when a firm is acquired by a PE company.

Our main finding is robust when we add firm-level controls, as we show in column 2 of table 4. Specifically, the model includes interactions between Post ${ }_{i t}$ and firm sales, earnings, leverage, profitability and cash flow. The point estimate is very similar in magnitude, which reassures that our findings are not driven by differences in firm attributes before the buyout period. Moreover, in column 3, we show the results when we further add to the model industry*year fixed effects. The results hold confirming that our conclusions are not driven by any contemporaneous changes in demand or any other time-varying industry characteristics. 
Finally, results hold when we estimate the equations with a probit model. Columns 4 and 5 report, respectively, estimates of the model without and with firm controls; column 6 shows the estimates when we add the industry* year fixed effects.

We conclude that private equity buyouts affect the extensive margin of exporting. These findings provide strong support for $\mathrm{H} 1 \mathrm{a}$ and the idea that private equity firms help companies grow and improve their operating performance relative to unsponsored peers. They suggest that PE-firms help targets to overcome the lack of expertise in reaching external markets, and cover financial costs.

\section{$5.2 \quad$ Intensive margin of export}

We now turn our attention to the impact of private equity backing on the intensive margin of exporting. Specifically, we examine how private equity buyouts affect the value of foreign sales and exporting intensity (i.e. foreign sales as a share of total firm sales). We estimate difference-in-differences models, and present the results in table 5. In columns 1 to 4 the dependent variable is the logarithm of the sterling pound value of export sales, and in columns 5 to 8 it the ratio of export sales to total sales. ${ }^{14}$

We focus on the sign and significance of the double-interaction term $\left(P E_{i} *\right.$ Post $\left._{i t}\right)$, which reveals whether private equity-backed firms are more likely to have a higher exporting intensity compared to our sample of control firms during the post-transaction period. We find that, following the buyout, the intensive margin of exporting is more sensitive for sponsored firms. Specifically, we find a positive and highly significant coefficient on the double-interaction term $P E_{i} *$ Post $_{i t}$, which implies that private-equity backed firms increase the value of their export sales by approximately 30 percentage points, relative to similar non-PE-backed firms. When we control for firm-level covariates in the pre-buyout period the statistical significance and economic magnitude of our baseline coefficient are barely affected (column 2). Finally, our results remain unchanged when we further include industry* year fixed effects to control

\footnotetext{
${ }^{14}$ In this exercise, we examine only companies that export; therefore, the number of observations diminishes relative to table 4 .
} 
for any potential time-varying, industry-specific variables such as contemporaneous changes in demand, and industry*year fixed effects (column 3).

Considering exporting intensity, in columns 4,5 , and 6 , we likewise, detect a significant effect of private equity ownership on the share of export sales to total sales. In particular, we find that exports as a share of total firm sales among buyout targets increases by around $2.5 \%$ more than in matched control firms. Once again, this is robust to the inclusion of firm controls (column 3), and sets of fixed effects.

In summary, our results provide strong empirical support for H1b as we observe that private equity-backed firms sell more abroad and have a higher exporting intensity relative to similar non-PE-backed firms. As know-how is a key resource for business, our findings suggest that private equity investors may provide financial and active strategic support to help companies accelerate their growth. $53 \%$ of $\mathrm{PE}$ investors in our sample have an international presence with offices in the UK and abroad. As a result, investors can bring expertise and experience of overseas markets, and act as a source of knowledge transfer for their portfolio firms, allowing them to reap the benefits of PE sponsorship via a growth in international sales.

\subsection{Credit constraints}

Our results thus far document an economically and statistically significant association between private equity ownership and exporting. We now turn to the hypothesis relating private equity investment, financial constraints, and exporting. Specifically, we test whether the identified effect is driven by easing credit constraints. We conduct three tests to observe the mechanism through which private equity investors alleviate financial constraints. First, in table 6 we split our sample into two groups of deals (private-to-private buyouts, and public-to-private buyouts \& divisional buyouts). This empirical exercise is motivated by prior studies that document heterogeneity in the firm-level effects of different buyout types. In particular, private-to-private transactions are associated with greater post-buyout growth 
relative to public-to-private buyouts and divisional buyouts (Boucly et al., 2011; Fracassi et al., 2018; Lerner et al., 2019).

In panel $\mathrm{A}$ of table 6 , we find strong evidence of post-buyout growth at both the extensive and intensive margins of exporting in private-to-private targets, with all coefficients significant at the $1 \%$ confidence level. At the extensive margin, private-to-private targets are around 6 percentage points more likely to be exporters relative to matched control firms. At the intensive margin, the value of exports grows by over $40 \%$ relative to matched control firms in private-to-private targets, while the coefficient on exporting intensity implies that the ratio of export sales to total sales increases by around $3 \%$ post-buyout in private-toprivate targets. Immediately, it appears that private-to-private buyouts are the driving force behind our main results.

By contrast, where take-private and divisional carve-out deals are concerned (panel B), the coefficients on the probability of exporting are statistically insignificant (columns 1 and 2 ), implying that targets of these transactions are not more likely to become exporters relative to control firms. Similarly, we do not find any impact on the value of exports (columns 3 and 4), or the share of exports to sales (columns 5 and 6). Overall, our results parallel prior work noting heterogeneity in post-transaction growth across various deal types, particularly private-to-private deals leading to positive firm growth relative to public-to-private deals (Boucly et al., 2011; Fracassi et al., 2018; Lerner et al., 2019).

We provide further evidence of private equity investors alleviating constraints in portfolio companies. In table 7, we identify large firms by looking at the top quartile of real total assets in the pre-buyout year and classify the remaining firms as small. Similarly, in table 8, we partition firms on the basis of their age, where we classify the top quartile of firms on the basis of their pre-buyout age as old, and the remainder of firms as young. We focus on the upper quartile of the distribution given that our sample largely contains relatively small firms. $^{15}$

\footnotetext{
${ }^{15}$ Bernstein et al. (2019) partition their sample of UK PE-backed firms in a similar manner.
} 
In columns 1 and 2 of table 7 we examine the probability of smaller and larger target firms exporting. The coefficients in columns 1 and 2 indicate that the positive effect on the probability of firms exporting is considerably stronger in magnitude and in significance on smaller target firms. The coefficients for larger firms are negative and statistically insignificant. Where the intensive margin of exporting is concerned, the differences between the coefficients on the export value of smaller and larger companies in columns 3 and 4 are statistically insignificant, implying private equity ownership's effect on export value is similar for both groups of firms. However, when we consider the exporting intensity of firms in columns 5 and 6 , the effect is strongly significant on smaller firms and suggests an increase of over 2 percentage points. The same coefficients for larger firms yield no statistical significance.

Finally, in table 8 we split our sample based on companies' pre-transaction age. The results in table 8 echo those in table 7: Companies that are younger and therefore more likely to be financially constrained, exhibit considerably higher post-transaction growth in exporting activity relative to older firms. Specifically, the coefficients in columns 1 and 2 concerning the probability of exporting show clear differences between younger and older firms. The coefficients on younger targets are positive and statistically significant at the $1 \%$ confidence level, implying the probability of exporting increases by over 5 percentage points, whereas the coefficients on older target firms are small in economic magnitude and statistically insignificant. Likewise, the coefficients on the intensive margin of export in columns 3 to 6 parallel those in table 7 . The coefficients on exporting intensity in columns 5 and 6 imply that the effect of buyouts on the post-transaction exporting intensity is only statistically significant for companies that are ex-ante more likely to be constrained; that is, younger firms. The coefficients regarding the value of exports are larger in magnitude for younger firms, but the difference is statistically insignificant from older target firms.

In summary, the results in tables 6, 7 and 8 provide strong empirical support for both H2a and $\mathrm{H} 2 \mathrm{~b}$. We find evidence that targets of private-to-private deals and targets that are ex- 
ante more likely to be financially constrained exhibit greater sensitivity of post-transaction growth in exporting to buyout transactions. Thus, availability of outside capital through private equity investment plays an important role when markets face higher trade costs and exporters require more external financing to meet these costs.

\section{Robustness tests}

We now put our findings through a battery of checks in order to investigate their robustness. We summarize these robustness tests below, but do not report them due to space constraints. They are available in the online appendix.

\subsection{Alternative matching methodologies}

Our results may be sensitive to the construction of the matched control group. We address this issue by adjusting our matching technique in two ways. First, we follow Bernstein et al. (2019) and tighten our matching bandwidths from 50\% to $30 \%$. This reduces our sample to

651 sponsored firms and 2,184 control firms. Second, we use the matching technique in Boucly et al. (2011) and drop leverage from the matching procedure, thereby allowing the two groups of firms to have different leverage ratios in the pre-buyout year. This increases our sample of private equity-backed firms to 935. We continue to find that private equity ownership positively affects firm-level exporting at both the extensive margin and the intensive margin. The baseline regression results when using these alternative matching methodologies are in tables A5 and A6. We confirm that our main results remain unchanged.

\subsection{Pre-buyout growth patterns}

One potential concern regarding the results presented thus far, is that private equity investors may simply choose to invest in companies that are already growing faster than other firms in the pre transaction period. Indeed, table 3 illustrates that PE-equity backed firms have 
higher sales growth rates in the pre deal years, and it may be that this is driving our results. In order to control for pre-buyout growth, we include an interaction term between the threeyear pre buyout growth rate in sales and the Post ${ }_{i t}$ variable. Thus, we estimate the following specification:

$$
y_{i c t}=\alpha_{t}+\alpha_{i}+\alpha_{c}+\beta_{1}\left(\text { PE }_{i} * \text { Post }_{i t}\right)+\beta_{2}\left(\text { SalesGr }_{i} * \text { Post }_{i t}\right)+\theta X_{i} * \text { Post }_{i t}+\varepsilon_{i c t}
$$

where SalesGr is the three-year growth in sales prior to the transaction year. We report the results in table A7 in the online appendix. Although we find that growth in pre buyout sales has a positive effect on the post buyout growth in the value of exports, its inclusion does not have a material impact on our estimates of private equity buyouts on firms' exporting activity. In other words, we find that it does not diminish the effect of private equity ownership, and our results remain intact after controlling for pre-buyout growth trends.

\subsection{Attrition bias}

In order to account for any potential attrition bias from firms exiting via acquisition or liquidation, we reduce our sample to include only those deals that experience an exit. The results are in table A8. This process of elimination reduces our sample of private equitybacked firms from 733 to 459. Nevertheless, the significance of our results concerning both the extensive and intensive margins of exporting remain intact. The magnitudes actually increase in size. The coefficients indicate that private equity-backed firms experiencing an exit increase the value of their exports by around $35 \%$ relative to control firms, and their export intensity increases by around $2.5 \%$. 


\subsection{Controlling for management buyouts (MBOs)}

We allow for the fact that after a transaction, new management teams may drive the improvement in firms' exporting. The difference-in-differences setting partly resolves this potential concern based on firm fixed effects for removing channels that may influence firms during the sample period. However, to ensure the robustness of our main results, we repeat our baseline estimations after dropping all management buyouts (MBOs) from the sample. An $\mathrm{MBO}$ is a buyout in which the existing management team takes a significant stake from the existing owners and therefore has increased incentives to improve operating performance. As such, Bernstein et al. (2019) suggest that MBOs may have lower engagement from PE investors. In our matched sample of deals, $44 \%$ of the private equity buyouts are MBOs. ${ }^{16}$ Table A9 presents the results, which demonstrate a significant impact of PE investment on both extensive and intensive margins of export. We conclude that the inclusion of MBOs does not have a material effect on our results.

\subsection{Controlling for secondary buyouts}

We also rerun the main specifications after dropping all secondary buyouts from our sample in table A10. Recent research finds the rationale and motives for secondary buyouts to differ from that of primary buyouts (Wang, 2012; Arcot et al., 2015; Degeorge et al., 2016). Accordingly, to control for the potential that including secondary buyouts may affect our results, we omit these deals from our sample and the main results hold. We continue to observe that PE ownership has a significant and positive effect on firm exporting at both the extensive and intensive margins.

\footnotetext{
${ }^{16}$ In our initial sample of all 3,310 UK buyouts from Capital IQ from 2004 to 2017, 40\% of deals are MBOs.
} 


\subsection{Investor experience}

To supplement our findings regarding deal level heterogeneity, we account for differences across PE investors by looking at their prior experience. We split the sample on the basis of investor experience and present the outputs in table A11. As more experienced PE firms invest more frequently in public-to-private buyouts and in larger portfolio companies, we expect their exporting behavior to be in line with the public-to-private buyouts in table 6 . We identify portfolio companies as backed by more experienced investors by taking the top quartile of investor experience at the time of the deal across four measures of experience: investor age, the number of funds raised, the value of funds raised, and the number of investments made. ${ }^{17}$ The results clearly show that investors' prior experience does not matter for portfolio companies' exporting performance.

We stipulate that the results are due to the fact that the oldest/largest GPs (general partners) are more prevalent in executing deals involving larger target companies and in engaging in more public-to-private buyouts. ${ }^{18}$ The probability to start exporting in international markets and the potential growth prospect in exporting is diminishing.

\subsection{Additional control variables}

Table A14 in the appendix offers a further robustness check, where we include controls that are widely used in the firm-level exporting literature. Typically larger, more productive firms export (Bernard and Jensen, 2004; Greenaway and Kneller, 2004). To test whether these firm-level variables may drive our results, and not the change in firm ownership, we

\footnotetext{
${ }^{17}$ The median investor age is 13 at acquisition, the median number of funds raised is three (at a median value of 1.1 \$billion) and the median number of prior buyout deals is 39 .

${ }^{18}$ This is consistent with the data. In table A12 in the appendix, we show that investors are, on average, significantly older and more experienced in the sample of public-to-private buyouts relative to the sample of private-to-private buyouts. For example, investors in public-to-private buyouts have on average raised funds totalling $\$ 12$ billion and executed over 450 buyouts deals. In comparison, investors in private-to-private buyouts have, on average, raised less than half of this amount ( $\$ 5.9$ billion) and have been involved in considerably fewer deal (117). These differences are strongly statistically significant. Moreover, in table A13 in the appendix, we also find that the most experienced investors typically invest in larger target firms. This is in line with Gompers et al. (2016), who present survey evidence showing that the target companies in deals of older, larger investors are considerably larger in size.
} 
augment our models in equations 4.1 and 4.2 with further controls, including the firm size, as measured by number of employees, labor costs and firm productivity, measured by profit per employee. As before, we take these controls in the pre deal year and interact them with the post variable. The results are consistent with our baseline results. In columns 1 to 4 we find that our results regarding firms' exporting at the extensive margin are unaffected by the inclusion of these further controls. Similarly, at the intensive margin, the coefficients still imply that private equity sponsorship is associated with an increase of over 30 percentage points in the value of firm's export sales. Where exporting intensity of firms is concerned, the coefficients imply a similar economic magnitude as our baseline results. In summary, we conclude that our main results are robust to including additional firm-level characteristics, typically associated with exporting firms.

\subsection{Further evidence on credit constraints}

Finally, we present further evidence that PE investors ease financing constraints for their portfolio companies. We split our sample on the basis of those defined as SMEs by the European Commission (EC). ${ }^{19}$ Under the EC guidelines, firms with a headcount of fewer than 250 and either turnover of less than 50 million euros or a balance sheet total of less than 43 million euros are SMEs. Given that SMEs are typically more likely to be constrained in access to financing, we partition the sample based on whether the firm is an SME. The results in table A15 are consistent with our findings so far, as we find that private equity ownership's effect on firm exporting is stronger for firms defined as SMEs by the EC, at both the extensive and the intensive margin.

\footnotetext{
${ }^{19}$ In unreported analysis, when we split the sample based on pre-deal firm leverage, likewise, the effect on firm exporting is greater on more leveraged (and hence more constrained) firms.
} 


\section{Conclusion}

Recent literature on corporate finance measures how private equity investment affects firm performance. Our study builds on these foundations, focusing on private equity buyouts and their effect on target firms' export performance. Our results from a panel of 733 private equity-backed firms and 3,104 control firms from 2004 to 2017 show that private equity investors are able to relax credit constraints, making their portfolio companies subject to fewer distortions and hence improving their exporting infrastructure. This effect holds for both the intensive and the extensive margin of export.

When we split our sample into different deal types and groups of firms, we uncover significant heterogeneity. In particular, the positive effect of private equity is more potent for private-to-private deals and financially constrained firms in the pre-buyout period. This finding implies that the availability of outside capital through private equity investment plays an important role when markets face higher trade costs and exporters require more external finance to meet these costs. Our results are robust to re-specifications and alternative matching methodologies.

Exporting provides many benefits to firms, including higher survival amid economic crisis. By helping their portfolio companies to increase their exports, private equity firms protect them from crises. This boon is particularly important now that the Covid-19 pandemic has badly hit the corporate sector. 


\section{References}

Acharya, V. V., Gottschalg, O. F., Hahn, M., and Kehoe, C. (2012). Corporate governance and value creation: Evidence from private equity. The Review of Financial Studies, 26(2):368-402.

Amess, K. (2003). The effect of management buyouts on firm-level technical inefficiency: Evidence from a panel of UK machinery and equipment manufacturers. The Journal of Industrial Economics, 51(1):35-44.

Amess, K., Stiebale, J., and Wright, M. (2016). The impact of private equity on firms patenting activity. European Economic Review, 86:147-160.

Arcot, S., Fluck, Z., Gaspar, J.-M., and Hege, U. (2015). Fund managers under pressure: Rationale and determinants of secondary buyouts. Journal of Financial Economics, 115(1):102-135.

Batt, R. and Appelbaum, E. (2014). Private equity at work. When wall street manages main street. Russell Sage Foundation.

Batt, R. and Appelbaum, E. (2020). The agency costs of private equity: Why do limited partners still invest? forthcoming in Academy of Management Perspectives.

Bernard, A. B. and Jensen, J. B. (1999a). Exceptional exporter performance: Cause, effect, or both? Journal of International Economics, 47(1):1-25.

Bernard, A. B. and Jensen, J. B. (1999b). Exporting and productivity. Technical report, National Bureau of Economic Research.

Bernard, A. B. and Jensen, J. B. (2004). Why some firms export. Review of Economics and Statistics, 86(2):561-569.

Bernard, A. B., Jensen, J. B., and Lawrence, R. Z. (1995). Exporters, jobs, and wages in u.s. manufacturing: 1976-1987. Brookings Papers on Economic Activity. Microeconomics, 1995:67-119.

Bernstein, S., Lerner, J., and Mezzanotti, F. (2019). Private equity and financial fragility during the crisis. The Review of Financial Studies, 32(4):1309-1373.

Bernstein, S. and Sheen, A. (2016). The operational consequences of private equity buyouts: Evidence from the restaurant industry. The Review of Financial Studies, 29(9):2387-2418.

Biesinger, M., Bircan, C., and Ljungqvist, A. (2020). Value creation in private equity. EBRD Working Paper No. 242, Swedish House of Finance Research Paper No. 20-17.

Black, J., Spowage, M., Cooper, B., McGeoch, A., and Watts, R. (2021). Estimating the relationship between exports and the labour market in the UK. UK Government report, Department for International Trade. 
Boucly, Q., Sraer, D., and Thesmar, D. (2011). Growth LBOs. Journal of Financial Economics, 102(2):432-453.

Chaney, T. (2016). Liquidity constrained exporters. Journal of Economic Dynamics and Control, 72:141-154.

Chung, J.-W. (2011). Leveraged buyouts of private companies. Available at SSRN 1904342.

Cohn, J. B., Hotchkiss, E. S., and Towery, E. (2020). The motives for private equity buyouts of private firms: Evidence from U.S. corporate tax returns. Available at SSRN 2318916.

Cohn, J. B., Nestoriak, N., and Wardlaw, M. (2021). Private equity buyouts and workplace safety. The Review of Financial Studies.

Cumming, D. J., Peter, R., and Tarsalewska, M. (2020). Public-to-private buyouts and innovation. British Journal of Management.

Davis, S. J., Haltiwanger, J., Handley, K., Jarmin, R., Lerner, J., and Miranda, J. (2014). Private equity, jobs, and productivity. The American Economic Review, 104(12):3956-90.

Degeorge, F., Martin, J., and Phalippou, L. (2016). On secondary buyouts. Journal of Financial Economics, 120(1):124-145.

Faccio, M. and Hsu, H.-C. (2017). Politically connected private equity and employment. The Journal of Finance, 72(2):539-574.

Fang, L., Ivashina, V., and Lerner, J. (2013). Combining banking with private equity investing. The Review of Financial Studies, 26(9):2139-2173.

Fracassi, C., Previtero, A., and Sheen, A. (2018). Barbarians at the store? Private equity, products, and consumers. Private Equity, Products, and Consumers (June 19, 2018). Kelley School of Business Research Paper, (17-12).

Gao, H., Harford, J., and Li, K. (2013). determinants of corporate cash policy: Insights from private firms. Journal of Financial Economics, 109:623-639.

Gompers, P., Kaplan, S. N., and Mukharlyamov, V. (2016). What do private equity firms say they do? Journal of Financial Economics, 121(3):449-476.

Greenaway, D., Guariglia, A., and Kneller, R. (2007). Financial factors and exporting decisions. Journal of International Economics, 73(2):377-395.

Greenaway, D. and Kneller, R. (2004). Exporting and productivity in the United Kingdom. Oxford Review of Economic Policy, 20(3):358-371.

Guariglia, A. (2008). Internal financial constraints, external financial constraints, and investment choice: Evidence from a panel of UK firms. Journal of Banking and Finance, 32(9):1795-1809. 
Guo, S., Hotchkiss, E. S., and Song, W. (2011). Do buyouts (still) create value? The Journal of Finance, 66(2):479-517.

Hadlock, C. and Pierce, J. (2010). New evidence on measuring financial constraints: Moving beyond the KZ index. The Review of Financial Studies, 23(5):1909-1940.

Harris, R., Siegel, D. S., and Wright, M. (2005). Assessing the impact of management buyouts on economic efficiency: Plant-level evidence from the United Kingdom. Review of Economics and Statistics, 87(1):148-153.

Ivashina, V. and Kovner, A. (2011). The private equity advantage: Leveraged buyout firms and relationship banking. The Review of Financial Studies, 24(7):2462-2498.

Jenkinson, T. and Sousa, M. (2015). What determines the exit decision for leveraged buyouts? Journal of Banking and Finance, 59:399-408.

Jensen, M. C. (1986). Agency costs of free cash flow, corporate finance, and takeovers. The American Economic Review, 76(2):323-329.

Kaplan, S. (1989). The effects of management buyouts on operating performance and value. Journal of Financial Economics, 24(2):217-254.

Kaplan, S. N. and Stromberg, P. (2009). Leveraged buyouts and private equity. Journal of Economic Perspectives, 23(1):121-46.

Lerner, J., Davis, S., Haltiwanger, J., Hanley, K., Jarmin, R. S., and Miranda, J. (2019). The economic effects of private equity buyouts. Harvard Business School Working Paper $20-046$.

Lerner, J., Sorensen, M., and Strömberg, P. (2011). Private equity and long-run investment: The case of innovation. The Journal of Finance, 66(2):445-477.

Manova, K. (2013). Credit constraints, heterogeneous firms, and international trade. Review of Economic Studies, 80(2):711-744.

Minetti, R., Murro, P., and Zhu, S. C. (2015). Family firms, corporate governance, and export. Economica, 82:1177-1216.

Minetti, R. and Zhu, S. C. (2011). Credit constraints and firm export: Microeconomic evidence from Italy. Journal of International Economics, 83(2):109-125.

Muûls, M. (2015). Exporters, importers, and credit constraints. Journal of International Economics, 95(2):333-343.

Schank, T., Schnabel, C., and Wagner, J. (2007). Do exporters really pay higher wages? First evidence from German linked employer-employee data. Journal of International Economics, 72(1):52-74.

Strömberg, P. (2008). The new demography of private equity. Technical report, New York: World Economic Forum USA. 
Wang, Y. (2012). Secondary buyouts: Why buy and at what price? Journal of Corporate Finance, 18(5):1306-1325. 


\section{Figures}

Figure 1: The effect of PE ownership on export activity

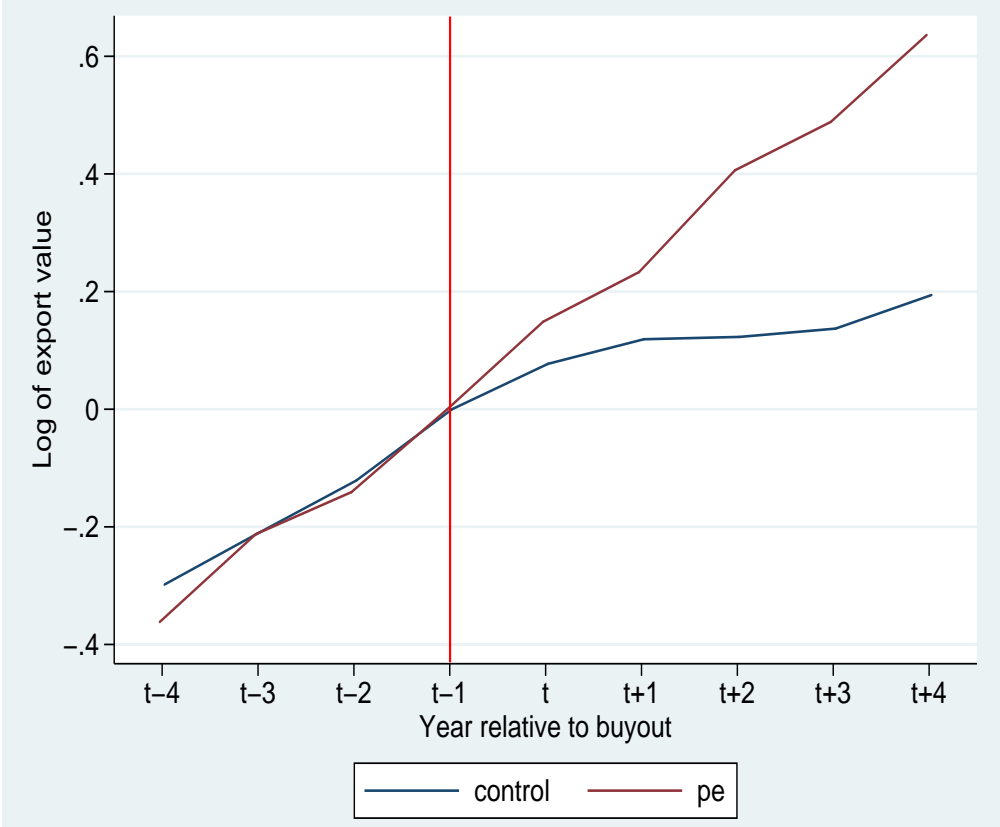




\section{Tables}

Table 1: Sample statistics

The table provides sample statistics on the transactions used in our study. Panel A displays the industry distribution of the target company involved in the transactions. Panel B describes deal types and panel C details the exit status of the deals.

\begin{tabular}{lcc}
\hline & Number & Percentage \\
\hline Panel A: Industry distribution & & \\
\hline Agriculture, forestry, fishing & 5 & $0.4 \%$ \\
Mining & 14 & $1.0 \%$ \\
Construction & 39 & $2.7 \%$ \\
Manufacturing & 344 & $24.2 \%$ \\
Transportation \& communication & 130 & $9.2 \%$ \\
Wholesale trade & 76 & $5.4 \%$ \\
Retail trade & 147 & $10.4 \%$ \\
Finance, insurance, real estate & 131 & $9.2 \%$ \\
Services & 530 & $37.3 \%$ \\
Public administration & 4 & $0.3 \%$ \\
\hline Panel B: Deal Type & & \\
\hline Private-to-private & 881 & $61.5 \%$ \\
Public-to-private & 79 & $5.5 \%$ \\
Secondary buyout & 228 & $15.9 \%$ \\
Divisional buyout & 245 & $17.1 \%$ \\
\hline Panel C: Exits & & \\
\hline Sale & 545 & $34.1 \%$ \\
Secondary buyout & 517 & $3.7 \%$ \\
Wro & & $36.3 \%$ \\
Other/Unknown & $266 \%$ \\
\hline
\end{tabular}




\section{Table 2: Descriptive statistics}

The table reports summary statistics for the pre-transaction year across PE-backed companies and control firms. PE-backed refers to all PE-backed companies; Control refers to a sample of non-PE-backed firms, matched on their two-digit SIC code, size (total assets), ROA (net income/total assets), and leverage (total debt/total assets) within a $50 \%$ bracket in the pre-transaction year. Log(export) is the natural logarithm of the value of export sales. Export intensity is exports as a percentage of total sales. Size is total assets, measured in thousands of pounds. Sales is total firm sales. Cash flow is net income plus depreciation and is scaled by total assets. Earnings is earnings before interest, taxes, depreciation, and amortization (EBITDA) normalized by total assets. ROA is the ratio of net income to total assets. Leverage is the ratio of total debt to total assets. Productivity is earnings per employee. All ratios are winsorized at $1 \%$.

\begin{tabular}{|c|c|c|c|c|c|c|c|c|c|}
\hline \multirow[b]{2}{*}{ Variable } & \multirow[b]{2}{*}{$\mathrm{N}$} & \multicolumn{3}{|c|}{$\mathrm{PE}$} & \multicolumn{4}{|c|}{ Control } & \multirow[b]{2}{*}{ Mean-dif } \\
\hline & & Mean & Median & SD & $\mathrm{N}$ & Mean & Median & SD & \\
\hline \multicolumn{10}{|l|}{ Exporting } \\
\hline Log(export) & 271 & 8.15 & 8.29 & 1.80 & 912 & 8.31 & 8.49 & 1.82 & -0.16 \\
\hline Export intensity & 271 & 0.29 & 0.18 & 0.30 & 912 & 0.34 & 0.22 & 0.32 & $-0.05^{* *}$ \\
\hline \multicolumn{10}{|l|}{ Firm Variables } \\
\hline Size & 733 & 98,961 & 18,625 & 394.238 & 3,104 & 76,693 & 15,181 & 332,988 & 22,267 \\
\hline Sales & 717 & 71,997 & 25,115 & 172,078 & 2,867 & 59,307 & 20,742 & 158.727 & $12,690^{*}$ \\
\hline Cash flow & 719 & 0.16 & 0.13 & 0.11 & 2,815 & 0.15 & 0.13 & 0.10 & 0.01 \\
\hline Earnings & 730 & 0.26 & 0.17 & 1.85 & 3,075 & 0.17 & 0.15 & 0.19 & 0.09 \\
\hline ROA & 733 & 0.12 & 0.10 & 0.10 & 3,104 & 0.12 & 0.09 & 0.10 & 0.00 \\
\hline Leverage & 733 & 0.63 & 0.63 & 0.26 & 3,104 & 0.63 & 0.63 & 0.22 & 0.00 \\
\hline Productivity & 701 & 24.26 & 17.01 & 20.65 & 2,692 & 25.50 & 17.14 & 22.15 & -1.24 \\
\hline
\end{tabular}




\section{Table 3: Growth rates}

The table displays three-year pre-transaction growth rates for firm-level variables across treated PE-backed and control firms. PE-backed refers to all PE-backed companies; Control refers to a sample of non-PE-backed firms, matched on their two-digit SIC code, size (total assets), ROA (net income/total assets), and leverage (total debt/ttal assets) within a $50 \%$ bracket in the pre-transaction year. Log(export) is the natural logarithm of the value of export sales. Export intensity is foreign sales as a percentage of total sales. Size is total assets, measured in thousands of pounds. Sales is total firm sales. Cash flow is net income plus depreciation and is scaled by total assets. Earnings is earnings before interest, taxes, depreciation, and amortization (EBITDA) normalized by total assets. $R O A$ is the ratio of net income to total assets. Leverage is the ratio of total debt to total assets. Productivity is earnings per employee. All growth rates are winsorized at $1 \%$.

\begin{tabular}{lccccccccc}
\hline & \multicolumn{9}{c}{ PE } \\
\hline Variable & $\mathrm{N}$ & Mean & Median & $\mathrm{SD}$ & $\mathrm{N}$ & Mean & Median & SD & Mean-diff \\
\hline Exporting - three-year rate & & & & & & & & & \\
Log(export) & 167 & 0.38 & 0.37 & 0.89 & 578 & 0.28 & 0.26 & 0.85 & 0.10 \\
Export intensity & 167 & 0.58 & 0.05 & 2.69 & 578 & 0.53 & 0.03 & 2.58 & 0.05 \\
\hline Firm variables - three-year rate & & & & & & & & & \\
Size & 678 & 1.81 & 0.50 & 8.17 & 2,740 & 1.86 & 0.32 & 9.05 & -0.05 \\
Sales & 557 & 0.75 & 0.36 & 1.55 & 2,164 & 0.62 & 0.25 & 1.56 & $0.13^{*}$ \\
Cash flow & 574 & 0.06 & 0.10 & 4.88 & 2,205 & 0.36 & 0.13 & 4.22 & -0.30 \\
Earnings & 585 & 0.48 & 0.12 & 4.72 & 2,435 & 0.44 & 0.06 & 4.39 & 0.04 \\
ROA & 495 & 0.81 & 0.23 & 1.56 & 2,088 & 0.85 & 0.26 & 1.53 & -0.03 \\
Leverage & 599 & -0.03 & -0.07 & 0.36 & 2,400 & -0.02 & -0.07 & 0.38 & -0.01 \\
Productivity & 498 & 0.39 & 0.30 & 0.87 & 1,881 & 0.36 & 0.24 & 0.83 & 0.03 \\
\hline
\end{tabular}




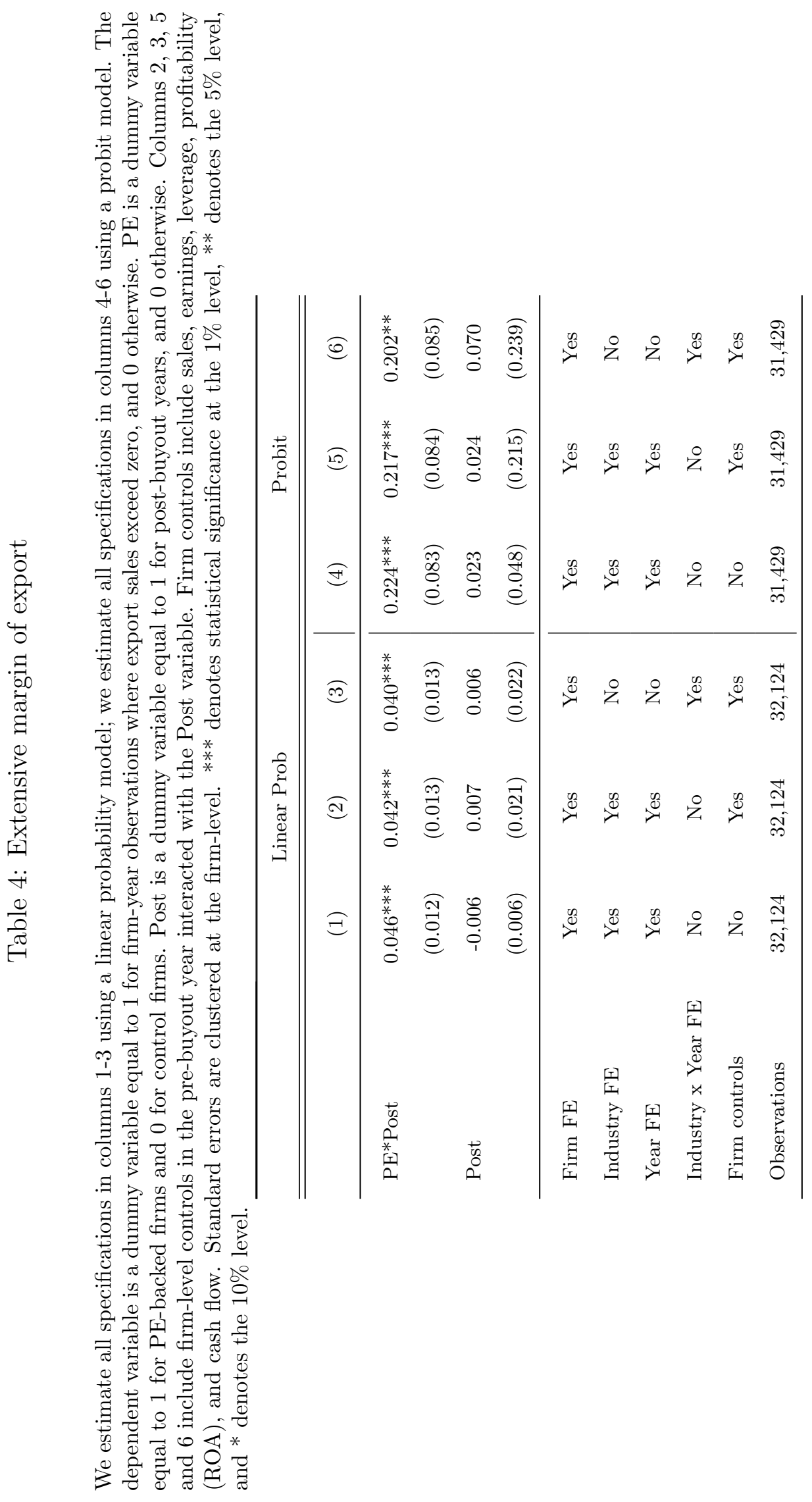




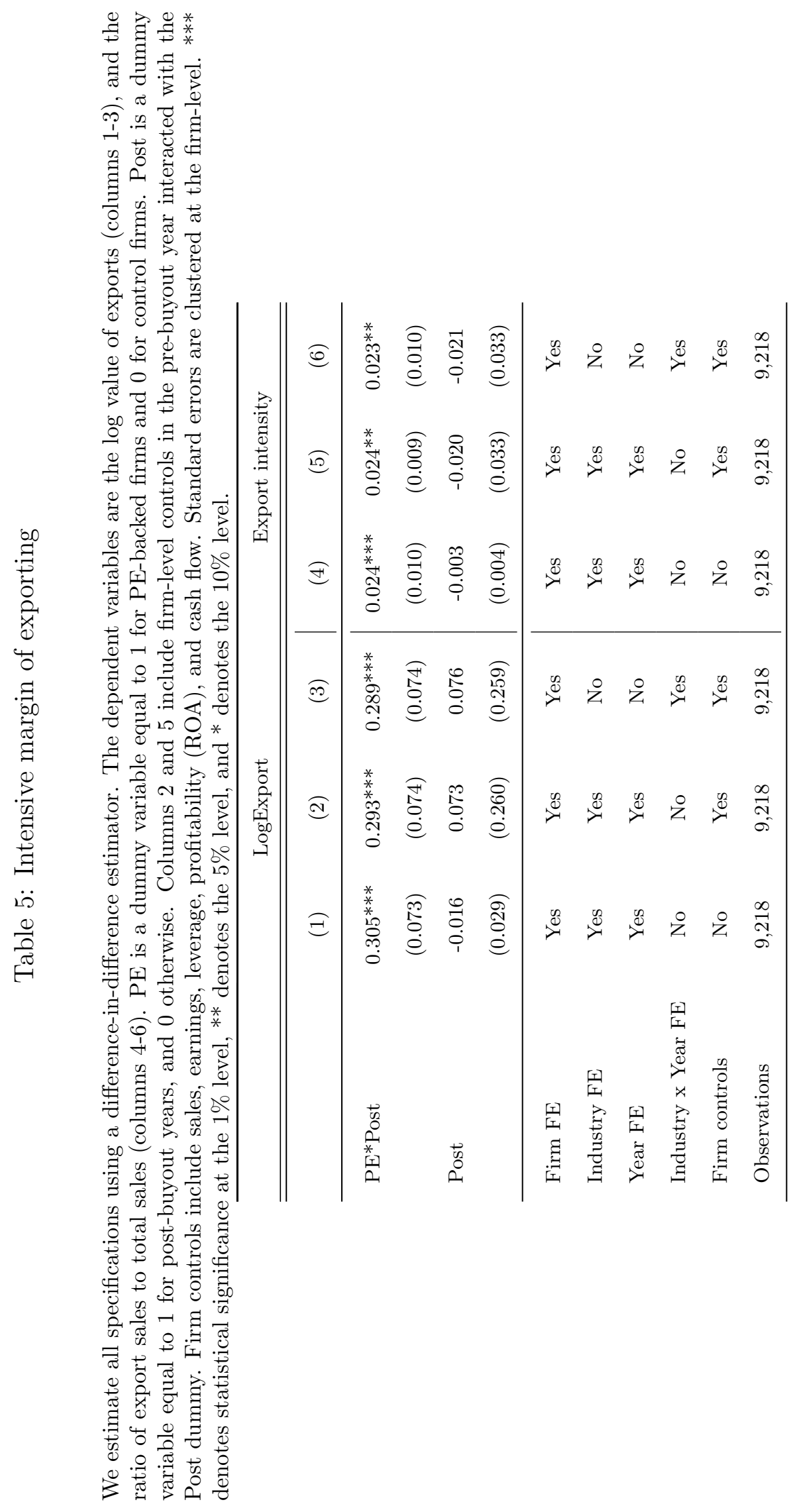




\section{Table 6: Deal types}

We estimate specifications in columns 1-2 using a linear probability model, and we estimate specifications in columns 3-6 using a difference-in-differences estimator. The dependent variables are a dummy variable equal to 1 for firm-year observations where export sales exceed zero, and 0 otherwise (columns 1-2), the log of export value (columns 3-4), and the ratio of export sales to total sales (columns 5-6). PE is a dummy variable equal to 1 for PE-backed firms and 0 for control firms. Post is a dummy variable equal to 1 for post-buyout years, and 0 otherwise. anel A shows results on the subsample of private-to-private buyouts. Panel B shows results on the subsample of public-to-private and divisional buyouts. In columns 2,4 and 6 we augment the baseline model with firm variables measured in the pre-buyout year, interacted with the Post dummy. Firm controls include sales, earnings, leverage, profitability (ROA) and cash flow. *** denotes statistical significance at the $1 \%$ level, $* *$ denotes the $5 \%$ level, and $*$ denotes the $10 \%$ level.

\begin{tabular}{|c|c|c|c|c|c|c|}
\hline & \multicolumn{2}{|c|}{ Exporting dummy } & \multicolumn{2}{|c|}{ LogExport } & \multicolumn{2}{|c|}{ Export intensity } \\
\hline & (1) & (2) & (3) & $(4)$ & $(5)$ & (6) \\
\hline \multicolumn{7}{|c|}{ Panel A: Private-to-private } \\
\hline \multirow[t]{2}{*}{ PE*Post } & $0.071^{* * *}$ & $0.064^{* * *}$ & $0.454^{* * *}$ & $0.444^{* * *}$ & $0.034^{* * *}$ & $0.034^{* *}$ \\
\hline & $(0.017)$ & $(0.018)$ & $(0.096)$ & $(0.097)$ & $(0.012)$ & $(0.013)$ \\
\hline \multirow[t]{2}{*}{ Post } & -0.005 & 0.011 & -0.050 & 0.110 & -0.001 & -0.043 \\
\hline & $(0.007)$ & $(0.025)$ & $(0.038)$ & $(0.327)$ & $(0.007)$ & $(0.047)$ \\
\hline Observations & 20,283 & 20,283 & 5,510 & 5,510 & 5,510 & 5,510 \\
\hline \multicolumn{7}{|c|}{ Panel B: Public-to-private \& divisional buyouts } \\
\hline \multirow[t]{2}{*}{ PE*Post } & -0.044 & -0.045 & 0.032 & -0.005 & 0.016 & 0.015 \\
\hline & $(0.030)$ & $(0.029)$ & $(0.134)$ & $(0.135)$ & $(0.019)$ & $(0.018)$ \\
\hline \multirow[t]{2}{*}{ Post } & -0.002 & -0.037 & 0.111 & 1.459 & -0.006 & 0.058 \\
\hline & $(0.014)$ & $(0.058)$ & $(0.078)$ & $(0.583)$ & $(0.009)$ & $(0.059)$ \\
\hline Observations & 5,385 & 5,385 & 1,741 & 1,741 & 1,741 & 1,741 \\
\hline Firm FE & Yes & Yes & Yes & Yes & Yes & Yes \\
\hline Industry FE & Yes & Yes & Yes & Yes & Yes & Yes \\
\hline Year FE & Yes & Yes & Yes & Yes & Yes & Yes \\
\hline Firm controls & No & Yes & No & Yes & No & Yes \\
\hline
\end{tabular}


Table 7: Financial constraints: Size

We estimate specifications in columns 1-2 using a linear probability model, and we estimate specifications in columns 3-6 using a difference-in-differences estimator. The dependent variables are a dummy variable equal to 1 for firm-year observations where export sales exceed zero, and 0 otherwise (columns 1-2), the $\log$ of export value (columns 3-4), and the ratio of export sales to total sales (columns 5-6). Large is a dummy variable that takes the value one if the firm's total assets are above the upper 25th percentile of the distribution of the total assets of all the firms, and zero otherwise. PE is a dummy variable equal to 1 for PE-backed firms and 0 for control firms. Post is a dummy variable equal to 1 for post-buyout years, and 0 otherwise. In columns 2, 4 and 6 we augment the baseline model with firm variables measured in the prebuyout year, interacted with the Post dummy. Firm controls include sales, earnings, leverage, profitability (ROA) and cash flow. *** denotes statistical significance at the $1 \%$ level, ${ }^{* *}$ denotes the $5 \%$ level, and * denotes the $10 \%$ level.

\begin{tabular}{|c|c|c|c|c|c|c|}
\hline & \multicolumn{2}{|c|}{ Exporting dummy } & \multicolumn{2}{|c|}{ LogExport } & \multicolumn{2}{|c|}{ Export intensity } \\
\hline & $(1)$ & $(2)$ & (3) & (4) & $(5)$ & $(6)$ \\
\hline \multicolumn{7}{|l|}{ Panel A: Large $=0$} \\
\hline \multirow{2}{*}{ PE*Post } & $0.080^{* * *}$ & $0.073^{* * *}$ & $0.297^{* * *}$ & $0.270^{* * *}$ & $0.024^{* *}$ & $0.023^{* *}$ \\
\hline & $(0.016)$ & $(0.017)$ & $(0.080)$ & $(0.081)$ & $(0.010)$ & $(0.010)$ \\
\hline \multirow[t]{2}{*}{ Post } & -0.007 & 0.008 & -0.011 & 0.242 & -0.001 & -0.009 \\
\hline & $(0.007)$ & $(0.019)$ & $(0.034)$ & $(0.348)$ & $(0.005)$ & $(0.042)$ \\
\hline Observations & 23,989 & 23,989 & 7,251 & 7,251 & 7,251 & 7,251 \\
\hline \multicolumn{7}{|l|}{ Panel B: Large $=1$} \\
\hline \multirow[t]{2}{*}{ PE*Post } & -0.015 & -0.025 & $0.347^{* *}$ & $0.342^{* *}$ & 0.026 & 0.028 \\
\hline & $(0.024)$ & $(0.024)$ & $(0.158)$ & $(0.161)$ & $(0.022)$ & $(0.023)$ \\
\hline \multirow[t]{2}{*}{ Post } & -0.005 & -0.031 & -0.043 & 0.456 & -0.007 & -0.116 \\
\hline & $(0.009)$ & $(0.021)$ & $(0.063)$ & $(0.749)$ & $(0.010)$ & $(0.115)$ \\
\hline Observations & 8,135 & 8,135 & 1,967 & 1,967 & 1,967 & 1,967 \\
\hline Firm FE & Yes & Yes & Yes & Yes & Yes & Yes \\
\hline Industry FE & Yes & Yes & Yes & Yes & Yes & Yes \\
\hline Year FE & Yes & Yes & Yes & Yes & Yes & Yes \\
\hline Firm controls & No & Yes & No & Yes & No & Yes \\
\hline Test of equality (P-value) for PE*Post & 0.001 & 0.000 & 0.389 & 0.344 & 0.000 & 0.000 \\
\hline
\end{tabular}


Table 8: Financial constraints: Age

We estimate specifications in columns 1-2 using a linear probability model, and we estimate specifications in columns 3-6 using a difference-in-differences estimator. The dependent variables are a dummy variable equal to 1 for firm-year observations where export sales exceed zero, and 0 otherwise (columns 1-2), the $\log$ of export value (columns 3-4), and the ratio of export sales to total sales (columns 5-6). Old is a dummy variable that takes the value one if the firm's age is above the upper 25th percentile of the distribution of the age of all the firms, and zero otherwise. PE is a dummy variable equal to 1 for PE-backed firms and 0 for control firms. Post is a dummy variable equal to 1 for post-buyout years, and 0 otherwise. In columns 2, 4 and 6 we augment the baseline model with firm variables measured in the pre-buyout year, interacted with the Post dummy. Firm controls include sales, earnings, leverage, profitability (ROA) and cash flow. *** denotes statistical significance at the $1 \%$ level, ${ }^{* *}$ denotes the $5 \%$ level, and * denotes the $10 \%$ level.

\begin{tabular}{|c|c|c|c|c|c|c|}
\hline & \multicolumn{2}{|c|}{ Exporting dummy } & \multicolumn{2}{|c|}{ LogExport } & \multicolumn{2}{|c|}{ Export intensity } \\
\hline & $(1)$ & $(2)$ & (3) & $(4)$ & $(5)$ & $(6)$ \\
\hline \multicolumn{7}{|l|}{ Panel A: Old $=0$} \\
\hline \multirow[t]{2}{*}{ PE*Post } & $0.058^{* * *}$ & $0.051^{* * *}$ & $0.304^{* * *}$ & $0.300^{* * *}$ & $0.026^{* *}$ & $0.027^{* *}$ \\
\hline & $(0.015)$ & $(0.015)$ & $(0.094)$ & $(0.095)$ & $(0.013)$ & $(0.012)$ \\
\hline \multirow[t]{2}{*}{ Post } & -0.010 & -0.020 & -0.008 & -0.175 & 0.001 & -0.032 \\
\hline & $(0.007)$ & $(0.018)$ & $(0.039)$ & $(0.35)$ & $(0.006)$ & $(0.050)$ \\
\hline Observations & 24,394 & 24,394 & 6,204 & 6,204 & 6,204 & 6,204 \\
\hline \multicolumn{7}{|l|}{ Panel B: Old=1 } \\
\hline \multirow[t]{2}{*}{ PE*Post } & 0.009 & 0.012 & $0.285^{* * *}$ & $0.288^{* * *}$ & 0.021 & 0.022 \\
\hline & $(0.031)$ & $(0.031)$ & $(0.106)$ & $(0.107)$ & $(0.015)$ & $(0.014)$ \\
\hline \multirow[t]{2}{*}{ Post } & 0.010 & $0.072^{*}$ & -0.021 & 0.467 & -0.008 & 0.007 \\
\hline & $(0.009)$ & $(0.031)$ & $(0.041)$ & $(0.333)$ & $(0.005)$ & $(0.031)$ \\
\hline Observations & 7,730 & 7,730 & 3,014 & 3,014 & 3,014 & 3,014 \\
\hline Firm FE & Yes & Yes & Yes & Yes & Yes & Yes \\
\hline Industry FE & Yes & Yes & Yes & Yes & Yes & Yes \\
\hline Year FE & Yes & Yes & Yes & Yes & Yes & Yes \\
\hline Firm controls & No & Yes & No & Yes & No & Yes \\
\hline Test of equality (P-value) for PE*Post & 0.000 & 0.000 & 0.448 & 0.464 & 0.000 & 0.000 \\
\hline
\end{tabular}

